\title{
Case study P: Political economy of the basic income grant in South Africa
}

\author{
Brian Mathebula
}

\section{INTRODUCTION}

In recent years, the basic income grant (BIG) discourse has gained attention worldwide as a potential policy option in social protection as testified by recent public debates, ongoing pilot projects, campaigning efforts, ${ }^{1}$ policy measures during Covid-19 and the surge in academic research. A BIG refers to regular cash transfers paid to all members of society irrespective of their socio-economic status, their capacity or willingness to participate in the labour market or having to meet pre-determined conditions (Offe 2008; Van Parijs 1995, 2003; Wright 2004, 2006). Despite the recent hype around BIG, Iran is the only country worldwide with a scaled-up BIG (Tabatabai 2011, 2012). Other programmes have never gone beyond pilot programmes. This raises the question why this is the case.

In South Africa, the BIG discussion re-emerged recently, partly in recognition of the economic impact of the Covid-19 lockdown and the government's announcement of a temporary (six months) social assistance grant aimed at the unemployed (18-59 years), who are not covered by any social protection scheme. In the same period, the Minister of Social Development, Lindiwe Zulu, stated that there were 'discussions' and the BIG has to be 'brought back to the table', because the BIG 'proposal will help realise the government's broader social security reform environment... will lift individual South Africans out of poverty'.

This case study discusses the political economy dynamics that influenced the policy non-take-up of the BIG in South Africa, following the adapted political settlement framework by Lavers and Hickey (2016). In their adapted political settlement approach, Lavers and Hickey (2016) argue that social protection adoption and implementation is driven by the political elite. The political settlement refers to how power is distributed amongst different groups in society (Di John and Putzel 2009), made up of formal ${ }^{3}$ and informal ${ }^{4}$ institutions (Khan 2010) that seek to influence the distribution of resources and decision making in society (Lavers and Hickey 2016). A political settlement is an outcome of bargaining and negotiation between elites to either constrain or facilitate institutional and developmental change (Di John

1 Andrew Yang's Freedom Dividend, of USD 1,000 per month: www.yang2020.com/policies/the -freedom-dividend/.

2 www.iol.co.za/mercury/governments-proposed-basic-income-grant-to-target-33m-south-africans -50992590 .

3 This refers to the rules of the game such as laws and constitutions (Lavers and Hickey 2016; Bender et al. 2017).

4 Informal institutions are based on patron-client politics with actors that have unequal power and status following internalised norms and values (Khan 2010). Political settlements in nature are based on clientelism as they accommodate and integrate the material interests of narrow political elites (van de Walle 2007). 
and Putzel 2009; DfID 2009; Lavers and Hickey 2016). Social protection is not formulated in isolation but as part of the overall distribution regime. The distributional regime refers to existing mechanisms for distributing resources within society.

\section{DETERMINING FACTORS FOR NON-TAKE-UP OF THE UNIVERSAL BASIC INCOME GRANT}

This section analyses how and why the BIG was proposed and opposed by the political settlement (policy coalitions), while also highlighting the broader paradigmatic ideas (prevalent norms and ideas) and the distribution regime that were central concerning the development of social security in South Africa.

\section{POLICY COALITIONS IN POST-APARTHEID SOUTH AFRICA}

After the unbanning of political parties in 1990, the African National Congress (ANC), Congress of South African Trade Unions (COSATU) and South African Communist Party (SACP) formed the tripartite alliance ${ }^{5}$ to contest the 1994 elections. COSATU aligned with the government in waiting (ANC) because it sought to put the worker's agenda at the forefront of the new political dispensation, and by 1999, the trade union had 15 of its senior members in senior positions in government (Barchiesi 1999). The labour union, envisioning a greater role in the development discourse (Ranchod 2007), wanted to go beyond mere representation of workers (Twala and Kompi 2012) and assert itself as a social movement by influencing broader social, political and economic issues (Chun and Williams 2013).

There was broad policy consensus within the tripartite alliance on welfare or social security. In 1994, the new government adopted the leftist and COSATU-SACP drafted document, the Reconstruction and Development Programme (RDP). The RDP lasted only two years before it was replaced by the neo-liberal Growth Employment and Redistribution, angering alliance partners who were sidelined in its drafting (Cedras and Kuye 2013). This was a deliberate move by the ANC to diminish the influence of its alliance partners in the political domain, as well as in policy formulation. The ANC had begun to embrace the neo-liberal project, which marginalised the alliance's redistributive mandate (Cedras and Kuye 2013). Over the years, the independence, role and influence of COSATU on policy matters within the alliance was diminishing (Twala and Kompi 2012; Masiya 2014), especially as democracy stabilised.

At the 1998 Presidential Jobs Summit, COSATU negotiated for the BIG to be included as part of the review for a comprehensive social security. The political feasibility of the BIG depended on COSATU building a strong constituency within the alliance to produce strong political demand for BIG as a policy option, which COSATU failed to do. Although the SACP supported the BIG proposal, COSATU was the only actor significantly advocating for the BIG (Matisonn and Seekings 2002). By 2001, the BIG Coalition, of which COSATU was

\footnotetext{
5 The ANC contests elections, while members of the SACP or COSATU are required to be members of the ANC in order to enter politics. ANC members are not required to be members of the SACP and COSATU (Cedras and Kuye 2013).
} 
a member, argued that the ANC and government had failed to engage with the idea of a BIG as a plausible policy option. The BIG was not rejected on the basis of compelling economic or social reasons (Naledi 2005). Despite broad support for the introduction of the BIG as part of a comprehensive social protection package by COSATU, the People's Budget Coalition ${ }^{6}$ and the BIG Coalition, there was no formal or transparent process within government for assessing BIG (Taylor Committee 2002).

The formal position of the ANC was to defer the Taylor Committee recommendations on the BIG, whilst government leaders were making hostile public statements on the BIG proposal (Coleman 2003). There were mixed messages on the BIG from various government departments, which made it difficult to distinguish supporters and detractors. The National Treasury (including the Finance Minister, Trevor Manuel) opposed the BIG, and viewed themselves as promoting fiscal responsibility (Seekings and Matisonn 2012). At the 2002 ANC policy conference, the ANC resolved to expand existing programmes, specifically raising the age eligibility for the child support grant. ${ }^{7}$

\section{4}

\section{PREVALENT NORMS AND IDEAS}

The new government in 1994 raised hopes that the plight of the black majority, which had been characterised by high levels of poverty, inequality and unemployment, would be reversed and diminished (Republic of South Africa 1994; Naledi 2005). The dismantlement of the apartheid system that had created skewed social and economic development based on race (Terreblanche 2002) was a key driver of ideas and norms for mobilising political support and development in the new South Africa.

The leftist, COSATU-SACP-drafted RDP (Cedras and Kuye 2013), including its broad ideas, grounded the formulation of policies across a wide spectrum, including social welfare (Gray 1998). The RDP states that access to social security for all is part of the development strategy (Republic of South Africa 1994). The White Paper on Social Welfare of 1997 introduced the concept of social protection as a development policy (Naledi 2005) and a review for a comprehensive social security for all South Africans recommended the BIG and stated that a gradual phasing-in was affordable. This also approached social protection as part of a broader development strategy (Taylor Committee 2002).

The rights-based approach enshrined in the Constitution of 1996 grounded the extension of social security to the black majority and was therefore another favourable condition for the introduction of the BIG. The Constitution guarantees access to socio-economic rights as a justifiable right and access to social security is a right for every individual who cannot provide for themselves and their dependants (Republic of South Africa 1996). The BIG Coalition ${ }^{8}$ argued to the Parliamentary Committee 'Social Services Select Committee' in 2002 that a BIG would entrench the constitutional right to social security, and should be promoted without a means

6 Members included COSATU, the South African Council of Churches and the South African Non Governmental Organisation Coalition.

7 www.sahistory.org.za/archive/2002-anc-national-policy-conference-closing-statement-jacob -zuma-30-september-2002.

8 There were over 20 organisations that were members of the BIG Coalition, including civil society, church organisations, non-governmental organisations, advocacy groups and organised labour. 
test. ${ }^{9}$ The absence of a means test in the BIG was opposed by the ANC as it meant that money would be transferred to the privileged white minority (Seekings and Matisonn 2012).

Despite the favourable conditions for a BIG such as broad support, the right to social security in the constitution and the high level of poverty, inequality and unemployment, these were combined with less favourable conditions, such as neo-liberal concerns as well as the financial constraints of the BIG.

A prevalent idea towards the BIG was that it would create a 'culture of dependency', as the Minister of Agriculture, Thoko Didiza, warned at the time. Thabo Mbeki (President of South Africa) and Joel Netshitenze (government spokesperson) raised concerns regarding unconditional 'handouts' to the poor and maintained that government should promote dignity through work (Seekings and Matisonn 2012). The view amongst the political elites was that the government should focus on promoting work ethic and wage labour discipline while stigmatising welfare 'dependency' (Barchiesi 2007). These ideas are closely associated with market-led and neo-liberal approaches to social protection, which were promoted through the market-driven, neo-liberal ideologies in growth employment and redistribution, promoted by the ANC.

The Minister of Finance, Trevor Manuel, raised concerns regarding the long-term affordability and administrative feasibility and labelled the BIG a 'populist' idea. In 2002, the BIG was opposed and subsequently shelved after an ANC policy conference because the ANC and government wanted to take a different philosophical approach to social protection, which included the promotion of public works and incremental means-tested social assistance (Seekings and Matisonn 2012), especially the child support grant, as compared to the BIG. ${ }^{10}$ The incremental extension was viewed as enabling the government to continue to reduce poverty and inequality, whilst also controlling spending.

\section{DISTRIBUTION REGIME}

An analysis of the post-apartheid distributional regime as a contributing factor enables an explanation for the non-take-up of the BIG in South Africa. The post-apartheid distribution regime has significantly demonstrated its commitment towards redistribution of resources via a subsequent development strategy, social services, social protection and taxation. Key indicators include: first, spending on the means-tested social assistance is around 4 per cent of gross domestic product, considered generous for a developing country. Second, the South African government views redistribution through progressive taxes and means-tested and pro-poor cash transfers as the most efficient way to address levels of poverty and inequality. Third, the means-tested social assistance programme enabled the government to decrease income inequality (Schiel et al. 2014; Woolard et al. 2010), whilst also achieving a positive impact in areas of poverty, health, education and empowerment (Samson et al. 2004; Woolard et al. 2010; Schiel et al. 2014; Satumba et al. 2017). Finally, the means-tested social assistance programme is identified as an important component of the development strategy in the National Development Plan-Vision 2030 (NPC 2012).

9 https://pmg.org.za/committee-meeting/1624/.

10 www.thenewhumanitarian.org/news/2007/11/29/social-grants-dependency-or-development-0. 
In general, a BIG represents a radical shift from current practice in the provision of cash transfers (Van Parijs and Vanderborght 2017). Following Pierson's 'path dependence' theory, defined as 'social processes that exhibit increasing returns' $(2000,252)$, the prevailing levels of welfare state spending created a 'path dependence', which continues to shape attitudes towards and non-take-up of the BIG. Although a BIG is considered and viewed as being redistributive (Standing 2008; Van Parijs 1995, 2003; Van Parijs and Vanderborght 2017), the success of the means-tested and pro-poor social assistance programme, with over 17 million recipients, enables the government to justify the current approach towards social assistance provision. The pursuance of the BIG in South Africa amidst the success of the means-tested social assistance programme runs counter to the path dependence literature. There could potentially be a political cost associated with the departure from policies that enjoy support from broad or influential political constituencies.

\section{CONCLUSION}

The ANC, despite a strong commitment towards reducing poverty and inequality, deliberately decided against a BIG arguing that the means-tested social assistance would enable the government to achieve its redistributive mandate while being fiscally responsible. The ANC managed to pull this through politically because proponents of the BIG within the alliance were unable to build a strong constituency to produce political support for the BIG. Once the means-tested programme is established and entrenched as part of the distribution regime, it is 'path dependent', meaning a shift towards BIG reform is challenging.

Although there are ongoing BIG discussions, including rhetoric from certain members of the political elites, the adoption of a BIG would require larger support from influential ANC constituencies and individuals. The Covid-19 experience, as well as rising levels of poverty, inequality and unemployment, will continue to raise pertinent questions for the political settlement, especially regarding the (permanent) extension of the means-tested and pro-poor social assistance programme to those aged between 18 and 59, who are not covered by any social protection schemes. It remains to be seen whether a BIG will be the answer.

\section{REFERENCES}

Barchiesi, F. (1999). Economic adjustment, political institutionalization and social marginalization: COSATU and the first democratic government (1994-99). Transformation 38, $20-48$.

Barchiesi, F. (2007). South African debates on the basic income grant: Wage labour and the post-apartheid social policy. Journal of Southern African Studies 33 (3), 561-75.

Bender, K., B. Rohregger, B. Kinuthia, G. Ikua, N. Pouw and E. Schüring (2017). Understanding multiple trajectories of extending social protection to the poor: An analysis of institutional change in Kenya. IZNE Working Paper Series: Nr 17/6. Sankt Augustin: Hochschule Bonn-Rhein-Sieg.

Cedras, J. and J.O. Kuye (2013). The impact of tripartite politics on the leadership function in public administration. Dialogue between the ANC, COSATU and the SACP in South Africa. School of Public Management and Administration. University of Pretoria 6 (3), 97-111.

Chun, J. and M. Williams (2013). Labour as a democratising force? Lessons from South Africa and beyond. Rethinking Development and Inequality 2 (April), 1-9.

Coleman, N. (2003). Current debates around BIG: The political and socio-economic context. www.tips .org.za/files/711.pdf 
DfID (2009). Political economy analysis: How to note (practice note). London: devenishj.soc.mtb.und. www.odi.org/sites/odi.org.uk/files/odi-assets/events-documents/3797.pdf

Di John, J. and J. Putzel (2009). Political settlements. Issue paper. Governance and Social Development Resource Centre. https://core.ac.uk/download/pdf/103642.pdf

Gray, M. (1998). Developmental Social Work in South Africa. Theory and Practice. Cape Town: David Philip Publishers.

Khan, M.H. (2010). Political settlements and the governance of growth-enhancing institutions. Draft Paper. London: SOAS, University of London.

Lavers, T. and S. Hickey (2016). Conceptualising the politics of social protection expansion in low income countries: The intersection of transnational ideas and domestic politics. International Journal of Social Welfare 25 (4), 388-98.

Masiya, T. (2014). Social movement trade unionism: Case of the Congress of South African Trade Unions. Politikon: South African Journal of Political Studies 41 (3), 443-60.

Matisonn, H. and J. Seekings (2002). Welfare in wonderland? The politics of basic income grant in South Africa, 1996-2002. 9th International Congress Geneva, 12-14 September. https://basicincome.org/ bien/pdf/2002MatisonnSeekings.pdf

Naledi (2005). The Basic Income Grant Coalition: Are universal cash transfers a feasible policy option for South Africa? A study of international examples of cash transfer programmes with specific reference to issues of targeting; grant administration; the financing of social security and the potential developmental stimulus of cash transfers. https://basicincome.org/bien/pdf/IsobelFryeFullPaper.pdf

National Planning Commission (NPC) (2012). National development plan 2030: Our future - make it work. Sherino Printers.

Offe, C. (2008). Basic income and the labor contract. Basic Income Studies 3 (1). https://doi.org/10.2202/ $1932-0183.1100$

Pierson, P. (2000). Increasing returns, path dependence, and the study of politics. American Political Science Review 94 (2), 251-67.

Ranchod, R. (2007). Between Consolidation, Promotion and Restoration: Trade Unions and Democracy in South Africa, Namibia, Zimbabwe and Swaziland. Cape Town: University of Cape Town.

Republic of South Africa (1994). The White Paper on reconstruction and development. Pretoria: Government Printer. www.gov.za/sites/default/files/governmentgazetteid16085.pdf

Republic of South Africa (1996). The Constitution of South Africa. Pretoria: Government Printer.

Samson, M., U. Lee, A. Ndlebe, K. MacQuene, I. van Niekerk, V. Ghandhi, T. Harigaya and C. Abrahams (2004). The social and economic impact of South Africa's social security system. EPRI Research Paper 37. Cape Town: EPRI.

Satumba, T., A.B. Seeraj and M. Seeraj (2017). The impact of social grants on poverty reduction in South Africa. Journal of Economics 8 (1), 33-49.

Schiel, R., M. Murray Leibbrandt and M. Lam (2014). Assessing the impact of social grants on inequality: A South African case study. WIDER Working Paper 160/2014 UNU-WIDER. https://doi.org/10 .35188/UNU-WIDER

Seekings, J. and H. Matisonn (2012). South Africa: The continuing politics of basic income. In M.C. Murray and C. Pateman (eds), Basic Income Worldwide. London: Palgrave Macmillan, 128-50.

Standing, G. (2008). How cash transfers promote the case for basic income. Basic Income Studies 3 (1). https://doi.org/10.2202/1932-0183.1106

Tabatabai, H. (2011). The basic income road to reforming Iran's price subsidies. Basic Income Studies 6 (1). https://doi.org/10.2202/1932-0183.1172

Tabatabai, H. (2012). Iran: A bumpy road toward basic income. In R.K. Caputo (ed.), Basic Income Guarantee and Politics. New York: Palgrave Macmillan, 285-300.

Taylor Committee (2002). Report of the Committee of Inquiry into a Comprehensive System of Social Security for South Africa, Transforming the Present - Protecting the Future. www.sarpn.org.za/C ountryPovertyPapers/SouthAfrica/march2002/report/i nde

Terreblanche, S.J. (2002). A History of Inequality in South Africa, 1652 to 2002. Pietermaritzburg: University of Natal Press.

Twala, C. and B. Kompi (2012). The Congress of South African Trade Unions (COSATU) and the tripartite alliance: A marriage of (in)convenience? Journal for Contemporary History 37 (1). 
van de Walle, N. (2007). The path from neopatrimonialism: Democracy and clientelism in Africa today. Working Paper 2007.03. Ithaca, NY: Mario Einaudi Center for International Studies, Cornell University.

Van Parijs, P. (1995). Real Freedom for All: What (if Anything) Can Justify Capitalism? Oxford: Clarendon Press.

Van Parijs, P. (2003). Real freedom for All: What (if Anything) Can Justify Capitalism? Oxford: Clarendon Press.

Van Parijs, P. and Y. Vanderborght (2017). Basic Income: A Radical Proposal for a Free Society and a Sane Economy. Cambridge, MA: Harvard University Press.

Woolard, I., A. Finn, M. Leibbrandt and J. Argent (2010). Trends in South African income distribution and poverty since the fall of apartheid. OECD Social, Employment and Migration Working Papers, No. 101. Paris: OECD Publishing.

Wright, E.O. (2004). Basic income, stakeholder grants, and class analysis. Politics and Society, 32 (1), 79-87.

Wright, E.O. (2006). Basic income as a socialist project. Basic Income Studies 1 (1). https://doi.org/10 $.2202 / 1932-0183.1$ 